\title{
The Relationship between English Pronunciation Self-concept and English Learning
}

\author{
${ }^{1}$ Hossein Talebzadeh, Ph.D. in TEFL, ${ }^{2}$ Leila Gholami, M.A. Student in TEFL
}

\author{
${ }^{1}$ Kharazmi University, Iran \\ Email: htmu88@yahoo.com \\ ${ }^{2}$ Kharazmi University, Iran \\ Email: I.gholami12@gmail.com
}

Keywords: Self-concept, English pronunciation, Classroom anxiety

\begin{abstract}
English pronunciation self-concept refers to self-evaluation of a person's English pronunciation proficiency which is shaped during the time spent for pronunciation learning (Gimson, 1980). The present paper aims at investigating the possible correlation between English pronunciation self-concept and English language learning. Furthermore, the relationship between global English self-concept and classroom anxieties are examined in the Iranian context. To this end, Xiuquan zhu's (2005) questionnaire was administrated to the total of 100 English as a foreign language (EFL) students. Moreover, to assess students general English performance and their pronunciation proficiency two kinds of tests were taken by the participants. Descriptive statistics was used to turn the raw data to the interpretable forms. The analysis revealed statistically significant correlation between English pronunciation self-concept and global English self-concept with in turn leads to efficient English language performance. However, negative correlation is obtained regarding English classroom anxiety and English pronunciation self-concept. Because of facilitating role of pronunciation self-concept in English language acquisition, the findings of the present study suggest that due attention should be paid on the English pronunciation self-concept in foreign language learning teaching-learning environments.
\end{abstract}

\section{Introduction}

\subsection{English pronunciation self-concept}

Pronunciation plays a pivotal role in the process of foreign language learning. Proper pronunciation and ability to understand other speakers can be of paramount importance for any English language learner. For good or bad, pronunciation is the most noticeable factor when people communicate for the first time. As a matter of fact, learning the skills and components of English language is somehow dependent on pronunciation for instance vocabulary learning is achieved by pronunciation processing of words. Delivery of speaking and listening is also through the medium of pronunciation (Gass \& Selinker, 2001). Whether we like it or not, English pronunciation is considered as an indicator of English proficiency in many EFL contexts. Such perception of English proficiency is even more pervasive when members of other disciplines gauge EFL learners' ability in English language. Chuming Wang (2004), posits that positive assessment of English pronunciation enhances one's motivation and consequently motivation factor dramatically influences one's overall performance in English language. On the other hand, negative assessment of one's pronunciation has weakening effect on learners' motivation. Self-concept is a concept related to psychology. Self-concept is defined as one's self-perception and self-assessment of their own abilities (Marsh, 2003). Self-concept is shaped by a person's experience from surroundings and how it is judged and comprehended by others (Hattie, 1986). Self-concept is not an internal element but it is a perception which influences language relevant behavior (Tang, Zhang, Yucogli \& Zhao, 2013). According to Marsh and Shawelson (1985), self-concept is divided into two categories of academic and non-academic self-concept. English self-concept belongs to academic category which itself is further classified into other sub-categories such as English reading self-concept, English pronunciation self-concept and so on (Marsh \& Yeung, 1993). Global English self-concept is the 
superlative notion which encompasses other dimensions of self-concept. Both global English selfconcept and other dimensions of self-concept are interdependent on one another. Improvement of one would impact on the other ones accordingly and vice versa.

\subsection{The effect of pronunciation self-concept on English language learning}

In fact, teaching and learning a language is an utterly complicated process. The complexity of language learning arises from nature of human beings. One can hardly question the role of affective filter and emotion in language learning process. When it comes to the role of pronunciation, even the case is more critical. Pronunciation is part of a person's identity and ego. There is also language ego which determines how open an individual should be to psychological and emotional factors. It is always stated that adult EFL learners develop psychological barrier towards pronunciation especially in the classroom contexts. The fear of exposure of their imperfect pronunciation causes them to keep silent in the classroom environment which leads to resistance in English learning. Even at times students tend to switch off in response to input provided to them. However, appropriate manifestation of pronunciation proficiency results in admiration on the part of both peers and teachers which enhances motivation and confidence (Horwitz, Horwitz \& Cpe, 1985). In line with the previous literature on the correlation between pronunciation self-concept and English proficiency, the present study tries to shed more light on this issue in Iranian context. Day by day, second language acquisition discipline realizes the significance of psychological factors in pedagogical environments. Self-concept is related to the field of psychology. Authorities in the realm of language teaching more and more is paying attention to the implications of psychological factors which facilitate language developments. However, Pronunciation self-concept and its psychological impacts has attracted scant attention in the process of learning-teaching English. Pronunciation learning is to some extent ignored in the Iranian contexts where English is a foreign language. Therefore, it is suggested that the attitude attached to teaching of pronunciations needs to be reconsidered in Iranian contexts. Moreover, teaching and learning of pronunciation should be at the focus of attention from the beginning of the learning-teaching process so that students obtain adequate motivation to sustain English learning. It is noteworthy to mention that teachers need to heed the significance of pronunciation self-concept and take action to form it in appropriate ways to foster language development. Pronunciation teaching does not just involve appropriate use of phonetic symbols or correct imitation but it should be concerned with learners' self-perception of their ability, the confidence of learning, and sustainability of learning (Tang, Zhang, Li, \& Zhao, 2013). The more psychological barriers are resolved, the more efficient pronunciation learning will be. As a result, a positive pronunciation self-concept leads to better grasp of language and better learning outcomes. The present study probes into the potential correlation between English pronunciation self-concept and English language learning by posing following research questions.

1. Is there any statistically significant relationship between Iranian EFL learners' English pronunciation self-concept and actual performance of English?

2. Is there any statistically significant relationship between Iranian EFL learners' pronunciation self-concept and global English self-concept?

3. Is there any statistically significant relationship between Iranian EFL learners' English pronunciation self-concept and English classroom anxiety?

4. Is there any statistically significant relationship between Iranian EFL learners' global English self-concept and each sub-dimension of it?

\section{LITERATURE REVIEW}

The concern on the formation of English pronunciation self-concept is a long-debated issue. Shavelson (1976) intended that self-concept is "a person's self-perception formed through experience and interpretations of their achievement. The individuals may specially influenced by significant others, reinforcement, and attributes for the individuals' own behavior" (p.413). It is believed that self-concept develops from childhood as individuals learn to identify themselves from 
others. By pass of time, novel experiences accumulate which are influenced by pas experiences. As individuals grow older they may feel more need to protect their fragile ego (Du, 2012). The results of Jing's (2006) study revealed that English self-concept also impacts on the application of learning strategies. So fostering English self-concept results in greater use of learning strategies which in turn leads to effective acquisition. Previously, self-concept was regarded as a unitary concept focusing on global nature of self-concept (Byrne, 1996; Wylie, 1979). Nevertheless, recent research conceives self-concept as a multi-faceted phenomenon. Academic self-concept interacts with academic performance which implies that changes in a certain type of self-concept influences and according performance (Marsh, Graven, and Melnerney, 2003). Chuming Wang (2004) proposing second language pronunciation learning hypothesis, highlighted that English pronunciation may improve or impede English acquisition. Nevertheless, English classroom anxiety also interacts with self-concept ( $\mathrm{Xu} \& \mathrm{Cao}, 2012)$. English pronunciation is shaped in the process of pronunciation learning. So English pronunciation proficiency influences students' self-perception of foreign language learners.

\section{METHOD}

This is a quantitative descriptive research aimed at investigating the potential correlation between English language pronunciation self-concept and English language learning.

\subsection{Participants}

The participants of the present study included 100 university learners majoring in TEFL, English literature, and English translation at Urmia University. The participants were chosen at random ranging from freshman to juniors at B.A. level. In this study the total sample size represents participants of both genders. With respect to age, participants ranged between 20 to 30 years of age.

\subsection{Instruments}

Two types of instruments were applied to collect research data. The first one is Xiuquan Zhu's questionnaire (2005) in which Likert's five-level scale is employed. The second instruments are global English tests and pronunciation tests which were administered to assess learners' English proficiency and their pronunciation skill.

\subsection{Procedure}

To gather necessary data, permission was sought from academic authorities of Urmia University. In the present study, 100 volunteers are chosen among whom there were 50 female and 50 male students majoring TEFL, English literature, and English translation. The majority of the participants had studied English for more than 4 years. The questionnaire was distributed in the second semester of the academic year. Participants were provided with the necessary instruction concerning the completion of the questionnaire. Furthermore, the purpose of conducting the study was explained. The questionnaire contained parts including the global English self-concept, the English pronunciation self-concept, and English classroom anxieties, the evaluation of others and the motivational factors in English language learning. With regard to the second instrument, the pronunciation test and global test were applied in the present study. In order to administer the pronunciation test, the volunteers were required to read ten sentences and one paragraph in English and audio samples were recorded. To increase the validity of the findings the audio samples were evaluated by two qualified faculty members of department of English language at Urmia University. The global test applied in the present study is a used version of MCHE Test which is national English as a foreign language test in Iran.

\subsection{Data analysis}

In order to analyze the collected data the social scientific software statistical package for the social sciences (SPSS) was used. 
Table 1. The correlation of global English self-concept and its dimensions

\begin{tabular}{|c|c|c|c|c|c|}
\hline & $\begin{array}{c}\text { Global } \\
\text { self-concept }\end{array}$ & $\begin{array}{c}\text { Pronunciation } \\
\text { self-concept }\end{array}$ & $\begin{array}{c}\text { Grammar } \\
\text { self-concept }\end{array}$ & $\begin{array}{c}\text { Listening } \\
\text { self-concept }\end{array}$ & $\begin{array}{c}\text { Reading } \\
\text { self-concept }\end{array}$ \\
\hline $\begin{array}{c}\text { Global } \\
\text { self-concept }\end{array}$ & 1.00 & 0.699 & 0.564 & .564 & 0.624 \\
\hline $\begin{array}{c}\text { Pronunciation } \\
\text { self-concept }\end{array}$ & 1.00 & 0.541 & 0.600 & 0.418 \\
\hline $\begin{array}{c}\text { Grammar } \\
\text { self-concept }\end{array}$ & & 1.00 & 4.365 & 0.502 \\
\hline $\begin{array}{c}\text { Listening } \\
\text { self-concept }\end{array}$ & & & 1.00 & 0.512 \\
\hline $\begin{array}{c}\text { Reading } \\
\text { self-concept }\end{array}$ & & & & 1.00 \\
\hline
\end{tabular}

As shown in Table 1, all the dimensions concerned correlated to global English self-concept. Among which pronunciation self-concept and reading self-concept ranked one and two. The pronunciation plays a significant role in global English self-concept; the change of pronunciation self-concept is likely to change the learner's global self-concept.

Table 2. The correlation of English pronunciation self-concept and the actual performance of English

\begin{tabular}{|c|c|c|c|c|c|}
\hline & $\begin{array}{c}\text { Maximum } \\
\text { value }\end{array}$ & $\begin{array}{c}\text { Minimum } \\
\text { value }\end{array}$ & $\begin{array}{c}\text { Average } \\
\text { value }\end{array}$ & SD & correlation \\
\hline $\begin{array}{c}\text { English } \\
\text { performance }\end{array}$ & $\mathbf{8 1}$ & 52 & 72.50 & 10.561 & 0.432 \\
\hline $\begin{array}{c}\text { Pronunciation } \\
\text { self-concept }\end{array}$ & 64 & 29 & 31.50 & 1.023 & 1 \\
\hline
\end{tabular}

As shown in Table 2, the correlation of English pronunciation self-concept to the actual performance of English is 0.325 .

Table 3. The correlation of English pronunciation self-concept and the global English selfconcept

\begin{tabular}{|c|c|}
\hline & The global English self-concept \\
\hline $\begin{array}{c}\text { The English pronunciation } \\
\text { self-concept }\end{array}$ & $\mathbf{0 . 4 9 7}$ \\
\hline
\end{tabular}

As shown in Table 3, the English pronunciation self-concept and the global English self-concept is significantly correlated. When the English pronunciation self-concept is high, the global English self-concept is high accordingly.

Table 4. The correlation of English pronunciation self-concept and English classroom anxieties

\begin{tabular}{|c|c|c|c|}
\hline & $\begin{array}{c}\text { The performance of } \\
\text { English } \\
\text { pronunciation }\end{array}$ & $\begin{array}{c}\text { The Actual } \\
\text { performance of } \\
\text { English }\end{array}$ & $\begin{array}{c}\text { The English } \\
\text { classroom } \\
\text { anxieties }\end{array}$ \\
\hline $\begin{array}{c}\text { English } \\
\text { pronunciation } \\
\text { self-concept }\end{array}$ & 1.258 & 1.364 & $\mathbf{- 0 . 0 7 4}$ \\
\hline
\end{tabular}

The English pronunciation self-concept to the performance of English pronunciation and the actual performance of English is not so correlated, but the English pronunciation self-concept and the English classroom anxieties is negative correlated. That is, the higher the English pronunciation self-concept is, the lowerthe English classroom anxieties. 


\section{DISCUSSION AND CONCLUSION}

The results of the present study indicates that all the sub-dimensions of global English including reading, listening, grammar, and pronunciation self-concepts correlate to global English self-concept. However, among the sub-dimensions, pronunciation plays a highly remarkable role which suggests that probability of any change of learners' global self-concept due to change in pronunciation self-concept is high. Regarding the relationship between pronunciation self-concept and actual performance of English, unlike the previous findings the present study did not reveal and significant correlation between the two variables. Such a result lies on the ground that participants of this study were adult foreign language learners whose language self-concept tends to be more multidimensional. Considering the self-concept and its pivotal role in overall academic achievement, stakeholders in the realm of English language teaching and learning are encouraged to take self-concept issue into account. On the other hand, individuals' maturity through their progress from childhood to adulthood causes individuals' self-concept to become more organized and complicated (Green, Nelson, Martin, Marsh, 2006). According to Marsh and Han (2003), there is a link between high levels of self-concept and academic outcomes. As a matter of fact, many students suffer from lack of pronunciation practice but unfortunately it has not earned enough attention from policy makers. As a result, students perceive their pronunciation ability as imperfect and find good reason to evade from speaking English. Even though their lack of self-esteem and motivation hinders their progress. Some teachers deem that pronunciation teaching belongs to the early phases of language development. So teaching pronunciation is neglected at higher level classes. Some teachers deem that pronunciation teaching belongs to early phases of language development. So teaching pronunciation is neglected at higher level classes. Universally, other components of language such as vocabulary learning gains more attention than pronunciation (Tang, Zhang, Li \& Zhao, 2013). The results of this study suggest that teachers as well as learners should be reminded of the importance of pronunciation teaching and learning and the role of positive pronunciation selfconcept. It seems imperative to pay attention to pronunciation even at the higher levels not only just elementary stages. Considering the role of pronunciation informing individuals' identity and language ego, it is recommended that pronunciation self-concept should be well established in the learners to achieve their ultimate success and make great use of their potentials. Moreover, pronunciation self-concept should be on the focus of attention from the early phases of language learning to achieve desirable results. In conclusion, pronunciation self-concept should be among top priorities of curriculum developers as well as course designers because of it is highly significant impact on academic as well as English proficiency. Further studies are needed to assess the relationship between academic success and self-concept, to illuminate on the link between academic records and self-concept, the relationship between motivation and the use of strategies, individual differences and self-concept, and how teachers' and learners' awareness on these issues can make a difference in students language developments.

\section{Reference}

[1] Byrne, B. M. (1996). Measuring self-concept across the life span: Issues and instrumentation. Washington: American Psychological association. http://dx.doi.org/10.1037/10197-000

[2] Chuming Wang. (2004). Self-concept, English pronunciation and EFL learning. Foreign Language Teaching and Research, 1, 56-64. http://dx.doi.org/10.3969/j.issn.10000429.2004.01.009

[3] Chuming Wang. (2004). English pronunciation self-concept and actual pronunciation performance. Foreign Language World, 5, 62-67.

[4] Du, M. (2012). A Study of the Relationship between English Self-concept and Language Learning Strategies. Journal of Language Teaching and Research, Vol. 3, No. 3, pp. 508-517 
[5] Gass, S., \& L. Selinker. (2001). Second language acquisition: An introductory course (2nd Ed.). New Jersey: Lawrence Erlbaum.

[6] Gimson, A. C. (1980). An introduction to the pronunciation of English (3th Ed.). London: Edward Arnold, Ltd.

[7] Green, J., Nelson, G., Martin, A. J., \& Marsh, H. (2006). The causal ordering self-concept and academic motivation and its effect on academic achievement. International Education Journal, 7(4), 534-546.

[8] Hattie, J. (1986). Self-concept. New Jersey: Erlbaum.

[9] Marsh, H. W. (2003). A reciprocal effects model of the causal ordering of academic selfconcept and achievement. Paper presented at NZARE AARE, Auckland, New Zealand November, MAR03755.

[10] Jiang, P. (1997). Importance of self-concept in foreign language teaching. Foreign Languages Research, 3, 64-65.

[11] Marsh. H. W., Graven, R. G., \& Melnerney, D. M. (2003). International advances in selfresearch. Charlotte: Information Age Publishing.

[12] Marsh, H. W., \& A. S. Yeung. (1993). Casual effects of academic self-concept on academic achievement structural equation models of longitudinal data. Journal of International Psychology, 89, 41-54.

[13] Shavelson, R. J., Hubner, J. J., \& Stanton, G. C. (1976). Self-concept: Validation of construct interpretations. Review of Educational Research, 46, 407-441.

[14] Tang, X., Zhang, S., Li, Y., \& Zhao, M. (2013). Study on Correlation of English Pronunciation Self-Concept to English Learning. English Language Teaching; Vol. 6, No. 4

[15] Xiuquan Zhu. (2005). the relationship of global English self-concept, English pronunciation self-concept and the English classroom anxieties. Journal of international affairs, 4, 61-65.

[16] Xu, s. \& Cao. Y. (2012). Research in relevance between the phonetic self-concept and English learning. Journal of Xinjiang Normal University (Social Sciences), 2, 98-101. 